\title{
President's Legislative Programs in the United States as a Non-monopoly and Non-commanding Power
}

\author{
Yu Zhaobo \\ School of Law, Beijing Institute of Technology, Beijing, the People's Republic of China \\ Email address: \\ yuzhaobo@263.net \\ To cite this article: \\ Yu Zhaobo. President's Legislative Programs in the United States as a Non-monopoly and Non-commanding Power. Social Sciences. \\ Vol. 10, No. 1, 2021, pp. 7-14. doi: 10.11648/j.ss.20211001.12
}

Received: December 23, 2020; Accepted: February 15, 2021; Published: February 26, 2021

\begin{abstract}
The president's programs are not monopoly and excluding, rather competitive and open to the members of congress; not commanding and abiding by, rather persuading and being persuaded; not comprehensively dominating the whole process of the Congress, rather only leading the legislative process of the Congress. The president 's programs exit in the State of the Union Address mostly. The reasons include the Constitution of the United States, the president itself and the congress itself ext.. The president's programs are based on separation, checks \& balance, are different from rights-reflecting legislative plans of England and China's autonomous legislative plans. China's autonomous legislative plans include three categories mandatory plans that must be completed when conditions are ripe, guiding plans that are ready to be completed as far as possible and researching plans that continue to be studied and considered according to circumstances. The president should struggle for his (or her) legislative programs to pass and is constraint of objective, subjective and externally environmental factors. Whether the president can successfully start the legislative programs of the Congress and whether each legislative project can pass through the legislative process of the Congress can be judged objectively by the president's public opinion support rate and party support rate, and subjectively by the president's subjective efforts, negotiation ability and persuasion ability, as well as the external environment when the president competes with the Congress, such as war or peace, economic situation, etc.
\end{abstract}

Keywords: Legislative Plan, U.S. President, U.S. Congress

\section{Introduction}

The legislative planning power of the United States president is directly reflected by the president's legislative programs. Statically, it refers to the legislative project proposed by the president; dynamically, the game between the president and the Congress develops, and the time flows to form a legislative plan. When it is converted to the two angles of power and right, the president 's programs is put on the table. The president's programs is a non-monopolistic and non-imperative "particular power". The non-monopoly originated from competition with Parliament members, the group of people with actual ownership (performance on average). The non-command is a customary practice based on historical tradition, which is more tacit rather than fixed.

\section{Viewing the President's Programs from Obama's State of the Union Address}

There are lots of sources of data for viewing or investigating the President's legislative programs [1] in different perspective. First of all, we should know the reason.

\subsection{Why the President's Programs Exist}

Under modern democratic politics, Congress has its objective conditionality of term, duration, time, and energy constraints. Therefore, each Congress must distinguish its priorities according to its needs and possibilities, conditions, and contexts, and then carry out the legislative activities according to their respective influence and abilities. It must be carried out step by step and in a planned way. The so-called "legislative plan" or "legislative outline" refers to the 
imagination and deployment of legislative work prepared by the subject with power to achieve a specific purpose, following certain rules, through specific procedures and using certain workmanship, within the scope of their functions and powers. As a bridge and link between proposal and deliberation, present and future, possibility and reality, ideas and specific provisions, legislative plans or outlines must exist in practice. To a large extent, it is because the unsatisfactory results of the established democratic decision-making process has already been recognized by the public. There they put forward the demand for a comprehensive program planning according to the plan, in this way, people can determine the actions of the government for a long time to come in advance.

\subsection{The Provision of the Federal Constitution on President's Programs}

For "the president's legislative plan (legislative project)", Article II (3) of the Federal Constitution of the U.S. clearly states that, "he (the president) shall report to the Congress on the situation of the Federation and propose to the Congress such measures as he considers necessary and appropriate for its consideration." In general, the union's state, the state of the union, and the state of the Union address are usually put forward to the president. In exceptional circumstances, the president may also make a special message. In this regard, some researchers in the U.S. pointed out that the state of the Union address, the state of the budget address, and the state of the economy address are enough to enable the president to set up "a comprehensive legislative program"[2] for the Congress. It can be seen that the state of the union is under the jurisdiction of the president. As for the source of power, as an official document between the president and Congress, the state of the Union address has the formal source of constitutional provisions, that is, "reporting the national conditions" in Article II(3) of the Federal Constitution of the U.S., the state of the Union address is mainly about the president's analysis of the federal national conditions and future vision, especially the president's legislative proposals and work priorities in this year.

\subsection{Analyses Taking the Case of 2012 and 2016 State of the Union Address}

In some sense, the President Biden' policies and legislation are similar to the former President Obama, therefore it is enough to analyze former President Obama. Take President Obama's State of the Union address ${ }^{1}$ in 2012 and 2016 as an example. In 2012, the state of the Union address proposed legislative plans including the following issues: (1) tax law;

1 Both the 2012 and 2016 state of the Union addresses are from the U.S. Congress website (www. Whitehouse. Gov).

For 2016, the link is:

https://www.whitehouse.gov/the-press-office/2016/01/12/remarks-president-barac k-obama -\% E2\% 80\% 93prepared delivery state Union address.

2012 Year link:

https://www.whitehouse.gov/the-press-office/2015/01/20/remarks-president-stateunion-address-January-20-2015 。 Last visit: October 20, 2016.
(2) illegal immigration; (3) innovation builds the foundation of the United States; (4) jobs bill; (5) Oppertunities for every responsible homeowner; (6) criminalization of fraud; (7) prohibition of insider trading by members of Congress; (8) requiring the Senate to pass a simple rule that all nominations for justice and public services must be voted in favor or negative within 90 days; (9) health care laws rely on the reformed private market and no longer rely on government programs. In 2016, the state of the Union address proposed legislative plans including issues as: (1) preferential legislation for criminal justice reform; (2) legislation against prescription drug and heroin abuse; (3) helping students; (4) personalized medical care; (5) repairing the broken immigration system; (6) controlling gun violence; (7) equal pay for equal work; (8) paid leave; (9) raising the minimum wage; (10) changing outdated regulations; (11) empowering the military to crack down on the Islamic state.

\subsubsection{The Multiple Positioning of the State of the Union Address}

First of all, we should understand the multiple positioning of the state of the Union address. As a speech, content of the state of the Union address has to consider the audience, including members of Parliament, legislative assistants, ordinary people, social organizations, etc., thus the language expression try to be general; as a report, the state of the Union address should reflect public opinion, take into account the requirements of clear logic and precise levels, and strive to be concise and theoretical; as a "speech-like report" and "report style speech" for about one hour, the state of the Union address should reflect public opinion, The state of the Union address involves static legislative projects. It can also present a dynamic, prioritized legislative plan, and even includes more specific content about legislative purposes, necessity, and feasibility.

\subsubsection{Analyses Using “Three-Division Method"}

Secondly, we should be clear about the American cultural characteristics of the state of the Union address. If we want to see the content of the "legislative plan" in the form of the Union address, we must understand the characteristics of American native cultural tradition and American thinking mode. The most normal thinking mode of the legislative plan of Chinese people is the "three-division method of legislative projects": (1) Legislative projects that must be completed when conditions are ripe can be called mandatory plans; (2) Legislative projects that are ready to be completed as far as possible can be called guiding plans; (3) Legislative projects that continue to be studied and considered according to circumstances can be called researching plans. The "three-division method" of the annual legislative agenda of the State Council of China is as follows: (1) projects to be completed within the year; (2) projects that need to be put forward to roll out in due; (3) projects that need to be actively studied and demonstrated. The "three parts law" of the five-year legislative plan of the Standing Committee of the National People's Congress: (1) the draft law submitted for deliberation during the term of office; (2) the draft law to be studied and drafted and arranged for deliberation when the 
conditions are ripe; (3) to continue to carry out research and argumentation, and to make corresponding arrangements according to the situation.

Through the form of "speech report" and "report speech" in the State of the Union address, and then interpret Obama's legislative plan in 2012 according to the thinking of "trichotomy", the results show that the first category of projects (mandatory plans) mainly include: (1) innovation act; (2) job creation act; (3) opportunity provision bill for homeowners; (4) Insider Trading prohibition bill for members of Congress; and (5) simple rules bill of the Senate. The second category of projects (guidance plan) mainly includes: (1) amending the tax law; (2) illegal immigration act; (3) health care bill. The third category of projects (research projects) mainly includes (1) legislation of fraud.

From the state of the Union address of the president of the United States, three types of legislative items can be interpreted, as well as more contents familiar to Chinese people, such as the legislative purpose of each legislation, the necessity, and feasibility of legislation, the main problems to be solved and the main system to be established by legislation. Take the STOCK Act as an example. (1) The purpose of the legislation is to turn the crisis of public trust and the corrosiveness of money politics around. Specifically, there are two purposes of legislation: one is to restore the public's trust crisis, including the people's distrust of Wall Street and the people's distrust of Congress members; the other is to put an end to the corrosive nature of money politics. If elected officials are allowed to own shares in industry and vote on it, it will inevitably lead to money politics' corrosiveness, so it must be restricted. (2) The necessity and feasibility of legislation are supported by both parties at the legislative ideas, at least outside the Washington D.C. Banning members of Congress from insider trading has indeed won strong support from the American people outside D.C., as well as from members of both parties in Washington. While, the latter is not so sure. It may be only verbal and public opinion support and may not support it in the actual voting. However, the legislation against insider trading has strong support from the public, oral help and public opinion support, so it is necessary and feasible to legislate. (3) There are two main problems to be solved by legislation: one is that elected officials can not only hold stocks but also exert influence on them; the other is the lobby to Congress for interests of interest group. (4) The system to be established by legislation: the general system is to prohibit members of Congress from insider trading, which is supported by two subsystems: one is that elected officials such as members of Congress are not allowed to own shares at the time when they can exert influence on the industry, and restrict members' voting and other policy-making behaviors. Second, people who raise money for Congress must not lobby Congress. That is, people in business fields such as Wall Street can not raise money for Congress at the time when they are lobbying the Congress.

\subsubsection{Other Ways to Exercise the President's Programs}

The president's State of the Union address can systematically and comprehensively launch his legislative program, start the annual legislative plan of Congress, and exercise the president 's programs over Congress. Budget address, economic address, and special address have the same function. Also, the president has other ways to exercise the legislative planning power: (1) interpersonal relationship. The president always tries his best to maintain good relations with key members of both Houses of the Congress, especially the leaders of the majority and minority parties in both Houses of the Congress and the speaker of the House of Representatives. He tries his best to persuade them to support the president's legislative proposals and form a "honeymoon" relationship like a lover despite different roles and roles, at least developing a cooperative relationship. (2) Special assistant. The president has set up special assistants to assist the legislative assistants of members of Congress in the drafting of bills and other specific work, cooperate with the select legislative committee to carry out the legislative investigation, legislative demonstration, legislative hearing, and other legislative preparations, and even directly deliver the bills drafted by the president.

\section{The Non-monopoly and Non-command of the President's Programs}

To understand the U.S. president's legislative planning power, we should weaken or eliminate the Chinese way of thinking and path dependence and make a judgment in line with the United States' actual situation. These are the two characteristics of the U.S. presidential non-monopoly plan.

\subsection{Non-monopoly and Non-exclusiveness of the President's Legislative Planning Power, But Competitiveness and Openness}

Legislative programs from the president are not the whole legislative program of Congress, not to mention the entire content of legislative deliberation in Congress. There are also legislative projects from senators and representatives, and Congress members have to consider other contents. The legislative plan proposed by the president is not mandatory and binding because the democratic legislative process fundamentally refuses to be required or bound; there are only persuasion and influence, as well as being convinced and influenced to accept voluntarily. In a strictly legal sense, the president of the United States has no legislative proposal power. The president's legislative projects are proposed in their respective houses through members of his party. Members are clear about the "rules of procedure". At the same time, it is also more apparent that the legislative items of some members come from the president rather than the nominal sponsors. Compared with the legislative items proposed solely by Congress members, the legislative items offered by the president are more in number and more important in content. They are more likely to be included in the legislative plan of Congress and thus be deliberated. There are fewer amendments in the deliberation, and the possibility of passing is excellent. Nevertheless, the president's legislative program is not monopolistic but 
competitive. It is dominated by competition with the items proposed by members. The so-called "the president of the United States monopolizes, exclusively and exclusively exercises the legislative planning power of Congress" is wrong and does not conform to the reality of the legislative planning power of the president of the United States.

\subsection{Non-command and Obedience Type, the President's Legislative Planning Power Is by Means of Influence and Persuasion}

The president's exercise of legislative planning power is not imperative, but by the voluntary acceptance of members of Congress based on the consideration of president's status, information, quality, needs, and rationality. If the president orders to do so, it would be a bad thing and arouse the disgust of members of Congress because members of Congress have no obligation to obey the president, and Congress and the president have equal status and equal power. As a matter of fact, when the legislative programs are related to the president's political interests, presidents allocate resources to the programs of their interests by asymmetrically using the information on efficiency. [3]

Members are elected through their election channels (their respective Constituencies), which is the same as the United States president is also selected through its electoral channels (National Constituencies). They all accept the orders from their respective voters and obey the will of their individual voters. There is no saying that "members obey the orders of the president". The main work of the president is to explain and mobilize members of Parliament to support the president, such as clarifying the importance and urgency of the bill and hoping that Congress will give priority to its legislative items on the agenda. The president's exercise of legislative planning power can not be ordered but persuasive. It is the relationship between proposal and deliberation, request, and decision-making. Although the president's proposal has more influence, and the request is more likely to be accepted, it is the only priority. The exercise process of legislative planning power is complex and tortuous, full of all kinds of uncertainty and uncontrollability, and there do not have the same existence as "presidential order".

The president's legislative planning power is not monopolistic and exclusive, but competitive and open; it is not command and obedience, but persuasion and persuasion. In this way, rather than saying that the president "owns" the legislative planning power of the Congress with $100 \%$ of the president's planning power, it is more accurate to say that the president "dominates" the legislative programs of the Congress, "greatly affects" the legislative planning process of the Congress, and even "practically controls" the legislative planning power of the Congress. Compared with the legislative proposals made by members of Congress, the president's legislative proposals are mostly put on the agenda, or even given priority to consider, rather than difficult to be included in the agenda; most of them will be deliberated by the Congress according to the president's ideas and logic. Legislative debates in Congress are often less, and it's more of consensus, rather than endless debates which makes the legislation process difficult to reach a consensus; At the end of the day, a bill similar to the president's proposal will be produced, rather than the final bill completely different from the original proposal. In short, the legislative agenda of the Congress is controlled by the president, and the areas and directions of the bill chosen by the Congress are affected by the president. The bill passed by Congress is the upgraded version of the bill proposed by the president.

\subsubsection{The President Not Comprehensively "Dominates" the Legislation of Congress}

In the words of American scholars, the president "dominates" the legislation of Congress, which means "Congress pays more attention to it": "the president's legislative proposals are not only almost always taken seriously by Congress but also leave room for the agenda, and the scope and content of the president's legislative programs will always become the backbone of national policy debates." [4] In the words of Chinese scholars, "the chances of enacting laws have increased": "the opinions reflected in the president's state address are not necessarily the opinions of the executive branch, but may also reflect the opinions of some commentators in Congress. No matter what the source of the opinions, once they are adopted as the opinions of the president, their authority will immediately increase, and the chances of enacting laws in the Congress will also increase." [5] "more attention" and "increased opportunity" accurately express that the president of the United States "dominates" the legislation of Congress.

\subsubsection{The Reason for President's Legislative Planning Power}

The legislative planning power of the United States president has two distinct characteristics: non-monopoly and non-command, which are caused by both the congress and the president.

First, rational consideration for Congress. Congress is an organ that can only exercise its power by holding meetings for discussion, decision-making, and meeting. It is suitable for making significant, long-term and fundamental decisions. In terms of legislation, it is reasonable to be used as a legislative platform and legislative place and for key legislative decisions such as deliberation, debate, and voting on the platform and site. It is impossible to take over all aspects, links, and procedures of legislation, that would be inefficient because the number of members of Congress is too large. There are 100 senators in the Senate and 435 representatives in the house of Representatives. Members are equal to each other and have no obligation to obey. It is difficult to reach a consensus on which bills to discuss and priorities. To get the support of other members and even the final passage of a member's proposal, it often takes a lot of time and energy to persuade. It even leads to the bad situation that members agree to vote for each other. Some of the bills are for the voters' benefit and even for the sake of political groups. In this way, Congress has inherent defects in the course of exercising power, the characteristics of members, and the purpose of the proposal. Also, the United States has always advocated freedom and prevailed in 
individualism, which makes it difficult for Congress to produce a unified legislative plan quickly, and thus loses the right to self-plan its legislation.

Second, the president's reason. Shortly, the president's bills can be discussed in a timely and efficient manner, and the president's daily work can be carried out in an in-depth manner for 24 hours, especially for day-to-day work. Among all the government officials in the United States, including members of Parliament and the chief justice, the president is the only one elected by the national voters. Since the president is the only government official elected by the people of the whole country, the people and Congress of the whole country hope that the president can put forward a legislative plan on all major issues. "national election" means that the president has a strong national public opinion base, not just in his constituency. The president is also the only head of the country, "the only representative of the head of the country" means that the president has a strong and clear sense of responsibility; in contrast, if there are many people, it is difficult to distinguish and investigate the responsibility. On a national basis, the president is aware of the overall legislative needs, so he can propose comprehensive, more realistic, and targeted legislative projects. In particular, the most critical legislative items in terms of content and most concerned by the American people, such as tax, budget, national defense, science and technology, civil rights, welfare, medical insurance, and other legislative items of the national economy and people's livelihood, are most qualified to be proposed by the president. In fact, they are often proposed by the president and discussed and approved by Congress. The president is responsible for both implementing the law and being aware of the legislative deficiencies and drawbacks that can only be exposed to law enforcement. The president has direct and personal feelings about the shortcomings and disadvantages, and even stings his skin. As a result, the president often resents the phenomenon of building a car behind closed doors and seeking a sword in a boat in the process of legislation and even more hates the so-called "waiting for a rabbit" and "whimsical" effect through legislation. In this way, the president has the same right to "amend the law" on the basis of the existing law. In short, whether from the perspective of work efficiency, public opinion basis or sense of responsibility, and whether it is for legislation or amendment, compared with members of Congress, the president is the first in lines to say in legislative items. It thus can actually exercise the legislative programs of Congress.

\section{A Comparison of the President's Programs of the United States with Britain and China}

\subsection{A Melting Power System in Britain}

In practice, Britain is a melting power system with legislative power and executive power, different from the separation of legislative power, executive power, and judicial power in the United States. In the United States, the president and the majority parties of both houses of Congress may belong to the same political party or the president may belong to the same party with only one place; in Britain, the Parliament and the government are composed of the same political party that wins the election, and the promises made by the ruling party (or government party) in the election program and policy address become the critical items of national legislation. The British government (or cabinet) has the legislative planning power of Parliament. The British government puts forward the legislative plan of Parliament, which is read out by the king for solemnity; in the British government, the legislative plan's specific maker is the legislative planning committee. In the process of legislative planning, "in order to strictly guarantee the quality of legislative planning, the British government has made necessary arrangements in the preparation process of legislative planning: first, it should be prepared one year in advance. Second, the legislative topics of each Ministry should be submitted to the competent Policy Committee of the cabinet for examination and approval. Third, the legislative issues of each Ministry shall be forwarded to the legislative planning committee after being approved by the competent Policy Committee. Fourth, the legislative planning commission will present the draft of its legislative planning proposals to the cabinet for examination and approval. "[6]

After the World War II, the British Parliament's legislative plan was entirely in charge of the government. The parliament lost the right to plan the legislation, but only focused on the debate, amendment, voting, and passing of legislation. Unlike the United States president, the British government does not need to fight for the legislative planning power of the parliament. What is required is that the legislative items proposed by the British government reflect the will of the people and make appropriate choices based on public opinion. If the legislative plan of the British government fails to reflect the rights and interests it represents, it will undoubtedly be attacked by the opposition parties and public opinion. The next election will be in a disadvantageous position and even be retaliated by the voters. In other words, the British government's legislative planning power is a reflection type of the legislative planning power.

\subsection{The Legislative Planning Power of the National People's Congress (NPC) in China}

The legislative planning power of the National People's Congress (NPC), the highest organ of state power in China, is not owned by the government (the State Council), at least not in name. Although the Standing Committee of the National People's Congress must consult the State Council when formulating legislative plans, and even the legislative opinions and items of the State Council play an essential role in the legislative plans. Since 1991, the Standing Committee of the Seventh National People's Congress has begun to plan legislation in the "Main Points of the Standing Committee's Work". Since then, the legislative plan has been continuously developed and improved. Now it is the Standing Committee of 
the National People's Congress that holds the legislative planning power of the National People's Congress. They frame the annual legislation plans, the 5-year long range legislation plans and the long-range legislative plans for more than five years. In other words, the highest organ of state power in China has independent legislative planning power, not the State Council. As for China's independent legislative planning power, Zhou Wangsheng's comment on the emergence of legislative planning shows that "China's legislation has taken another positive step in the process of becoming scientific. There is another right prescription for changing the legislative situation of treating headache and foot pain separately and the emergence of the plan showed a progress action by step approach. "[7] Cai Dingjian is optimistic about that, "the NPC's legislation can be focused, planned and executed step-by-step with the legislative plan and the annual legislative plan. It enabled the Standing Committee of the National People's Congress from the passively acceptance mode of the proposals of the State Council and other units in the past, to the initiator role to clarify the tasks and put forward requirements for the drafting departments of legislative proposals with the legislative plan. After the change, the Standing Committee of the National People's Congress can avoid the passive situation of knowing nothing about the draft law before it is submitted to the Standing Committee of the people's Congress for deliberation, as in the past. The legislative role of the Standing Committee of the National People's Congress has changed from passive to active. "[8]

\subsection{President's Programs Attributed to the Balanced Legislative Planning Power}

Compared with Britain's reflective legislative planning power and China's independent legislative planning power, the U.S. president's programs belongs to the balanced legislative planning power. In terms of fundamental power division, the Congress has legislative power. In a strict sense, the president has no legislative power but only has the capability of checks and balances based on the legislation of Congress, which can restrain and balance the legislation of Congress. The designer of the Federal Constitution of the United States explained in the Federalist Papers that "to prevent legislative tyranny". People never seem to think of the usurpation danger from the legislation. If all powers are concentrated in the hands of some people, it will inevitably lead to the same tyranny as under the threat of administrative usurpation. The centralization of power will inevitably lead to tyranny. This is the case with administrative authority and the same with legislative power. Therefore, the Federal Constitution of the United States grants legislative authority to Congress, and at the same time provides that the president can check and balance the legislative power of Congress. The U.S. president's checks and balances on the legislation of Congress are mainly exercised through the president's legislative plan, Legislative Veto, and Presidential Signing Statement.

Therefore, onlookers will always see the president and Congress arguing over the issue of legislation.

\section{Non-monopoly and Non-command Determine That the President Should Fight for the Legislative Programs}

The president's legislative programs belongs to the type of check and balance, which is only "dominant". Therefore, the president must fight for the legislative programs of Congress and "fight for rights". "It's the job of the president to legislate for the United States of America." [9] Whether the president can successfully start the legislative programs of the Congress and whether each legislative project can pass through the legislative process of the Congress can be judged objectively by the president's public opinion support rate and party support rate, and subjectively by the president's subjective efforts, negotiation ability and persuasion ability, as well as the external environment when the president competes with the Congress.

\subsection{Objective Preconditions for the President's Programs}

First, objectively. The objective preconditions for the president's struggle for legislative planning power include the president's public opinion support rate, the party's support rate, and the party's "consensus-building" level.

The higher the president's popular support rate is, the greater the president's legislative planning power will be. With the high public opinion support rate of the president, members can see that more "votes" are supporting the president. Members will make the choice of "obtaining these votes", which is hard to say for the sake of justice, but only for the needs of political achievements, especially for re-election, both senators and representatives. If you go with a president with a large number of votes, you will have more options; if you go with a president with fewer options, you will have fewer options. Senators or congressmen are "afraid of retaliation from voters if they oppose a popular president or support an unpopular president" [10]; their rational choice is to walk with the president with high public support and alienate the president with low public support. Generally speaking, the president who wins by a significant advantage has more legislative planning power than the president who wins by a weak advantage; while the president wins with a high public opinion during his term of office, his legislative planning power is also increasing, and vice versa.

The president's legislative planning power is also related to the support rate of political parties. If the presidential party controls both the house of Representatives and the Senate, then the president's legislative planning power will be more significant, and the president will have more legislative items on the agenda of the Congress and the items will finally be passed; if the presidential party only controls one house or controls even none, then the president's legislative planning power will be small, and the president's legislative projects will go through ups and downs in the legislative process, even death. In the first two years of Clinton's term of office, the presidential party controlled both houses of Congress and the house of Representatives, and the probability of the bill passed 
in the legislative process of Congress was as high as $85 \%$; in the second two years, the presidential party controlled only one house, and the probability of Clinton's bill passing through the legislative process of Congress dropped vertically to one of the lowest after the War II [11].

The support rate of the president's political party depends on the party's "consensus-building" level. If the president's party can reach a consensus and concentrate the people's will (Party members and members), then the members of the party will support the president on the legislative items, and the non-party members will join in the fun. Even the members of the opposite party may "rebel" and vote for the president's legislative project. "Consensus building" is very important to the political party support rate of the president of the United States because the American political party is an endogenous political party, the ideas of the party are complex, and the members of the Congress have no obligation to obey the president of their own party. Endogenous political parties, as opposed to exogenous political parties, refer to the Parliament (or parliament or parliament or people's Congress) first, and then spontaneously generate political parties within the parliament. On the contrary, exogenous political party means that there are political parties first, then Congress, and then Congress under political parties' leadership. The logic of the emergence of endogenous political parties is that Congress is a place for "ruling by leaders", which can embody democracy. Still, it is often at the cost of sacrificing efficiency. It is precisely under the strong demand of "efficiency" that political parties will inevitably emerge within Congress. Members of Congress are equal to each other, and there is no command or obedience. Members of Congress should fight for the rights and interests of constituencies and make decisions for federal deliberation. When faced with significant issues that require members to choose, there are bound to be two different attitudes: Radicalism and moderation, two different views from "hawks" and "doves", and two distinct camps of "left" and "right". Over time, political parties will appear in Congress. There is no mention of "political party" in the Federal Constitution of the United States; The Federalist Papers, which interprets and defends the Federal Constitution, also rejects factions and party struggles. But demand is the best soil. The evolution and development of the Democratic Party and the Republican Party, the two endogenous political parties in the U.S. Congress, have proved this point. The emergence of political parties can greatly simplify complicated procedures (including legislative procedures) and improve decision-making efficiency (including legislative decisions). To analyze the endogenous political parties in the United States from another perspective, if they belong to the same party, it must mean the necessary consistency in ideological trends, theoretical views, policy propositions, etc. The same political party is only "basically consistent". On the basis of "basic consistency", the ideas within the party are still complex, and the presidential party still needs to constantly "build consensus" for the constantly improvement of the level of consensus. If this is the case, it will provide a strong impetus for the expansion of the president's legislative planning power; on the contrary, the political parties with a low level of "consensus-building" and low ability will inevitably have smaller legislative planning power.

\subsection{Subjective Preconditions for the President's Programs}

Second, speak from the president's subjective aspect. The president's fight for the right to plan is not to wait for the right to legislate. The president, as an individual, is the dominant mode of the president's executive power; it is rooted not so much in the formal mechanism as in the personal bargaining and persuasive ability of the president.

In practice, only the president's subjective efforts can successfully exercise the legislative planning power in Congress. "The power and status of the president are the premise and the ability of the president to discuss and persuade will enable its legislation to be passed by Congress." [12].

The president's subjective initiative and active discussion and consultation can continuously break down the barriers of members of Congress, narrow the differences, and expand the basis of unity and consensus.

\subsection{External Environment for the President's Programs}

Third, speak from the external environment. Whether the president can start the legislative plan of the Congress and whether each legislative item can pass the legislative procedure of the Congress depends on the objective and subjective reasons of the president to the Congress, as well as the external environment in which the legislation is made, such as war or peace, economic situation, etc.

When the external environment is peaceful, the atmosphere is the first to consider. In war, there is a tendency to increase executive power at the expense of legislative power. In a war environment, the power of the president is in expansion, and the legislative planning power of the constituent part of the president's power is also considerable; in a peaceful environment, the president's power is in limitation, and the president's legislative planning power is also in limitation. The executive power of the president is often more closely related to efficiency. War requires special and urgent affairs, including legislation. The legislative power of Congress is often integrated with democracy. Only in peacetime does the reality of legislative needs allow the Congress to spend a lot of time and energy to discuss the legislative issues repeatedly and democratically. The second in consideration is the economic environment. If the economy has deteriorated when the new president takes office, the president will have more legislative planning power, more legislative items, the higher probability of passing, less modification by the Congress, and a shorter time for deliberation by Congress. President Roosevelt took office during the great depression in the 1930s, and Obama took office in the financial crisis in 2009. Their legislative planning power has clearly proved this. With the optimization of the economic environment, such as the gradual recession of the economic depression and the gradual disappearance of the financial crisis, the president's legislative programs tend to be 
difficult and embarrassing in Congress, It is also tricky and changeable for the president to exercise the power of legislative planning.

\section{References}

[1] Samuel Kernell, Roger Larocca, Huchen Liu, et al. New Data for Investigating the President's Legislative Program. 2019, 49 (2): $330-357$.

[2] PIKA A, NORMAN C T, RICHARD A. The politics of the presidency $[\mathrm{M}]$. Washington, D. C.: Congressional Quarterly Inc., 1994: 202.

[3] Kim, BH (Kim, Bong Hwan): The president and asymmetric use of information [J]. Applied Economics Letters, 2019, 26 (14): 1214-1217.

[4] RUDALEVIGE A. Managing the president's program (presidential leadership and legislative policy formulation) [M]. Princeton and Oxford: Princeton University Press, 2002: 3.

[5] Wang Mingyang. American administrative law (I) [M]. Beijing: China legal press, 1995: 139.
[6] Jiang Jinsong. Legislative planning in Britain [J]. National People's Congress work bulletin, 1996 (2): 37-38.

[7] Zhou Wangsheng. Some theoretical issues on legislative planning $[\mathrm{J}]$. Journal of Peking University (PHILOSOPHY AND SOCIAL SCIENCES), 1993 (3): 49.

[8] Cai Dingiian. The development and historical transformation of the legislation of the people's Congress in the past 20 years [M] / / Cai Dingjian, Wang Chenguang. Development and reform of the people's Congress in the past 20 years. Beijing: China procuratorial press, 2001: 59.

[9] MAYHEW R. Divided we govern party control, lawmaking and Investigations 1946-2002 [M]. New Haven and London: Yale University Press, 2005: 2.

[10] BOND R, RICHARD F, DAN W. The marginal and time-varying effect of public approval on presidential success in Congress [J]. The Journal of Politics, 2003, 65 (1): 92-110.

[11] BRANDON C, STEVEN A. Enduring rivals: presidential success and support in the house of representatives [J]. Congress \& The Presidency, 2006 (33): 21-46.

[12] RICHARD E. Presidential power: the politics of leadership [M]. New York: John Wiley \& Sons, 1964: 35. 